\title{
A Treaty for the Rich and Politically Loyal? Explaining the Bilateral Center-Region Treaties in Post-Soviet Russia
}

\author{
Ekaterina Paustyan | ORCID: 0000-0002-4646-0550 \\ Postdoctoral researcher, Professorship of Institutional Ecomomics, \\ Faculty of Business Studies and Economics, University of Bremen, \\ Bremen, Germany \\ paustyan@uni-bremen.de
}

\begin{abstract}
This paper studies the signing of bilateral treaties between the federal and regional governments of Russia in the period of 1994-1998. Fuzzy-set Qualitative Comparative Analysis of 64 cases suggests that by signing bilateral treaties in exchange for political support President Yeltsin built a broad coalition with subnational leaders. This strategy allowed Yeltsin to win the 1996 presidential election but, in the long run, contributed to the preservation of authoritarian enclaves in Russia. The results are in line with the argument that authoritarian consolidation in Russia during the 2000 s was deeply embedded in the center-region relations of the 199 os.
\end{abstract}

\section{Keywords}

Russia - center-region relations - bilateral treaties - QCA

\section{Introduction}

Over the last three decades, the Russian Federation has undergone a gradual transformation from subnational authoritarianism to national autocracy. Under Putin, the ability of regional elites to deliver electoral results has become a crucial element of intra-elite bargaining and territorial politics in Russia more 
generally. ${ }^{1}$ As this pattern largely emerged before Putin, ${ }^{2}$ studying the centerregion relations of the 1990s can shed light on the sources of authoritarian consolidation in Russia in the 200os. The present study concentrates on the period of 1994-1998, when the governments of more than 40 regions negotiated bilateral treaties with Moscow. While previous studies either explain why some regions signed the treaties earlier than others ${ }^{3}$ or concentrate on their legal aspects, ${ }^{4}$ more puzzling is the question of why some regions managed to negotiate a treaty while others did not. This is important for our understanding of the balance of powers between the center and the Russian regions as well as the ways how subnational and national politics interact with each other.

To reveal the factors motivating the signing of bilateral treaties, the study takes a 'causes-of-effects' perspective on causality focusing on why certain cases have specific outcomes rather than on estimating the average effect of certain independent variables. ${ }^{5}$ Qualitative Comparative Analysis (QCA), introduced by Ragin, ${ }^{6}$ provides more opportunities for making inferences regarding the cases. It can uncover necessary and sufficient conditions accounting for the occurrence of an outcome as well as for its non-occurrence. Furthermore, QCA can untangle complex causal relations and reveal different paths leading to the same outcome, thus making it useful for understanding the treaty signing process. This is one of the first studies that utilize QCA and configurational logic to explain center-region relations in Russia. Combining institutional and actor-centered arguments, ${ }^{7}$ the analysis examines the interplay of such factors

1 Grigorii V. Golosov, "The Regional Roots of Electoral Authoritarianism in Russia", Europe-Asia Studies 63, no. 4 (2011): 623-639.

2 William M. Reisinger and Bryon J. Moraski, The Regional Roots of Russia's Political Regime (Michigan: University of Michigan Press, 2017).

3 Peter J. Söderlund, "The Significance of Structural Power Resources in the Russian Bilateral Treaty Process 1994-1998", Communist and Post-Communist Studies 36, no. 3 (2003): 311-324. David Dusseault, Martin Ejnar Hansen and Slava Mikhailov, "The Significance of Economy in the Russian Bilateral Treaty Process", Communist and Post-Communist Studies 38, no. 1 (2005): 121-30.

4 Jeffrey Kahn, Federalism, Democratization, and the Rule of Law in Russia (Oxford: Oxford University Press: 2002).

5 James Mahoney, "After KKV: The New Methodology of Qualitative Research", World Politics 62, no. 1 (2010): 120-147. Gary Goertz and James Mahoney, A Tale of Two Cultures: Qualitative and Quantitative Research in the Social Sciences (Princeton: Princeton University Press, 2012). Ingo Rohlfing, Case Studies and Causal Inference: An Integrative Framework (Hampshire: Palgrave Macmillan, 2012).

6 Charles C. Ragin, The Comparative Method (Berkeley: University of California Press, 1987).

7 Mikhail Filippov, Peter C. Ordeshook and Olga Shvetsova, Designing Federalism: A Theory of Self-Sustainable Federal Institutions (New York: Cambridge University Press, 2004). Heather L. Tafel, "Regime Change and the Federal Gamble: Negotiating Federal Institutions 
as demanding sovereignty, having an elected executive, voting for Yeltsin in the 1996 presidential election, and the status of a donor region. Fuzzy-set QCA of 64 cases reveals two sufficient combinations of conditions accounting for a signed treaty, namely, voting for Yeltsin in the 1996 presidential election and either having the status of a donor region or having an appointed executive.

These results suggest that by signing bilateral treaties in exchange for political support President Yeltsin built a broad coalition with subnational leaders. This strategy allowed Yeltsin to win the 1996 presidential election, yet, in the long run, enabled the preservation of subnational authoritarian regimes in Russia-as bilateral agreements were signed with both democratic- and authoritarian-leaning governors. This is in line with the argument by Gibson ${ }^{8}$ that the persistence of regional authoritarian enclaves is conditional upon the strategies of territorial control pursued by the local elites as well as the strategies of governance and coalition-building employed by a national leader. By providing a configurational perspective on the treaty signing process in Russia, this study has laid out new empirical evidence confirming the argument that the authoritarian consolidation in Russia in the 2000 s was enabled by the center-region relations of the 1990s. ${ }^{9}$

The paper is structured according to the standard protocol of QCA. The first section conceptualizes the outcome and provides background on the bilateral treaties. The second section reviews relevant literature and lists the main conditions that are expected to produce the outcome. The third section describes the methodology, data, and the calibration strategy. The fourth section presents and discusses the results. The final section concludes.

\section{Russia's Emerging Federalism and the Bilateral Treaties of $1994-1998$}

The formation of the Russian Federation in the 1990s was largely predetermined as a federal arrangement could best accommodate the interests of both

in Brazil, Russia, South Africa, and Spain", Publius: The Journal of Federalism 41, no. 2 (2011): $257-285$.

8 Edward L. Gibson, Boundary Control: Subnational Authoritarianism in Federal Democracies. (Cambridge: Cambridge University Press, 2012).

9 Vladimir Gel'man, "The Dynamics of Sub-National Authoritarianism: Russia in Comparative Perspective", in Vladimir Gel'man and Cameron Ross eds., The Politics of Sub-National Authoritarianism in Russia (Burlington: Ashgate Publishing Company, 2010): 1-18. Golosov, (2011) and Reisinger and Moraski, (2017). 
the center and the regions. ${ }^{10}$ There was no consensus, however, "on the inherent value of the federal project" among the federal and regional elites. ${ }^{11}$ The projects varied from a proposal to create a symmetrical federation with all subnational units being equal in their status to a suggestion to preserve only the ethnic regions while merging other regions together. ${ }^{12}$

Eventually, in March 1992, the regional and federal governments signed the Federation Treaty (federativnyi dogovor) that determined the extent of autonomy for the regions within the federation. ${ }^{13}$ The governments of the republics of Chechnya and Tatarstan, however, refused to sign the Federation Treaty and insisted on the negotiation of separate agreements with the center. ${ }^{14}$ The first treaty was initially prepared for Chechnya in October 1992, yet negotiations again failed. ${ }^{15}$ In the meantime, preparatory work on the treaty with Tatarstan had started. The bilateral treaty (dogovor) was finalized and signed in February 1994 following the adoption of the new Constitution of the Russian Federation in December 1993. This bilateral treaty was accompanied by additional agreements (soglashenia) on foreign economic relations, banking, monetary and exchange policies, fiscal relations, military affairs, and crime prevention. Due to these agreements, Tatarstan obtained sufficient economic autonomy and could follow its own privatization plan, leave a larger sum of tax revenues in the regional budget, and establish relations with foreign states. The bilateral treaty also recognized a separate, subnational citizenship of Tatarstan, and acknowledged that the republican authorities could deal with its 'issues.'

Once the treaty with Tatarstan had been signed, governments in other regions attempted to negotiate similar agreements. Sergey Shakhray, a Deputy Prime Minister and a Chair of the State Committee for Federalism and

10 Irina Busygina, Mikhail Filippov and Elmira Taukebaeva, "To Decentralize or to Continue on the Centralization Track: The Cases of Authoritarian Regimes in Russia and Kazakhstan", Journal of Eurasian Studies 9, no 1 (2018): 64.

11 Jeffrey Kahn, "The Parade of Sovereignties: Establishing the Vocabulary of the New Russian Federalism", Post-Soviet Affairs 16, no. 1 (2000): 58-89. Kahn, (2002): 145.

12 Nicholas J. Lynn and Alexei V. Novikov, "Refederalizing Russia: Debates on the Idea of Federalism in Russia", Publius: The Journal of Federalism 27, no. 2 (1997):187-203. Busygina, Filippov and Taukebaeva, (2018): 64 .

13 Andrey Starodubtsev, Federalism and Regional Policy in Contemporary Russia (New York: Routledge, 2018).

14 Nail Mukharyamov and Olga Senatova, "Tsentr i Regiony: Opyt Predotvraschenia Konfliktnykh Situatsii", Politicheskii Monitoring, June 1995. http://igpi.ru/monitoring/ 1047645476/jun1995/centr.html (accessed 15 March 2017).

15 Sergey Shakhray, "Formula Tatarstanskogo Dogovora Rodilas v Groznom", 3 December 2014, https://www.youtube.com/watch?v=eg8qPoUSbiM (accessed 24 August 2017). 
Nationalities Policy, stated that "it is legally and economically possible to conclude treaties similar to the one signed with Tatarstan with each subject of the Russian Federation."16 In July 1994, President Yeltsin officially established a special commission to deal with the preparation of bilateral treaties with the regional governments, with Shakhray being appointed as chairman of this commission.

Between 1994 and 1995, six more treaties were signed with the republics of Kabardino-Balkaria, Bashkortostan, North Ossetia, Sakha, Buryatia, and Udmurtia. In 1996, Sverdlovsk Oblast became the first region with a predominantly ethnic Russian population that negotiated a treaty with the center. In total, 46 regions signed 42 'extraconstitutional' treaties between 1994 and $1998 .{ }^{17}$ The treaties defined the general principles of the division of powers between regional and federal governments. ${ }^{18}$ Each treaty was supplemented by additional agreements that concerned specific policy areas. Their number, as well as scope, varied from region to region "depending on particular policy concerns and resource endowments." 19

The treaty signing process was discontinued following the appointment of Vladimir Putin as the Chairman of the Presidential Commission for the Preparation of Treaties in July 1998. After being elected president in 2000, Putin established a special commission to examine the extent to which bilateral treaties were in line with the Constitution and federal legislation. ${ }^{20}$

16 Quoted in Kahn, (2002): 157. It is quite likely that the First Chechen War that started in 1994 made the treaty signing process more feasible.

17 This discrepancy is because some Russian oblasts and krais have administrative jurisdiction over autonomous okrugs located on their territory. Therefore, when a treaty was signed with Irkutsk and Perm oblasts as well as with Krasnoyarsk Krai, the autonomous okrugs constituting their parts also received a treaty. As the governments of okrugs were also parties in the treaty, these treaties were trilateral in fact.

18 Steven Solnick, "Federal Bargaining in Russia", East European Constitutional Review 4, no 4 (1995): 52-58. Alfred Stepan, "Russian Federalism in Comparative Perspective", Post-Soviet Affairs 16, no. 2 (2000): 133-176. Cameron Ross, "Federalism and Inter-Governmental Relations in Russia", Journal of Communist Studies and Transition Politics 26, no 2 (2010): 165-187. Inga Saikkonen, "Variation in Subnational Electoral Authoritarianism: Evidence from the Russian Federation", Democratization 23, no. 3 (2016): 437-58.

19 Kathryn Stoner-Weiss, "Central Weakness and Provincial Autonomy: Observations on the Devolution Process in Russia", Post-Soviet Affairs 15, no 1 (1999): 91. This paper acknowledges the differences among the agreements but does not consider them in the empirical analysis as data are limited and very fragmented - the texts of agreements are available only for 19 out of 42 treaties. As a result, the analysis focuses on bilateral treaties alone.

20 Cameron Ross, "Putin's Federal Reforms and the Consolidation of Federalism in Russia: One Step Forward, Two Steps Back!" Communist and Post-Communist Studies 36, no. 1 (2003): 29-47. 
Eventually, all treaties had been canceled by the mid-20oos. The government of Tatarstan managed to negotiate a new treaty in 2007, which, however, expired in 2017. With its expiration, the era of bilateral agreements between the federal government and the regions had come to an end, marking a new phase in center-region relations in Russia.

\section{Conditions of a Signed Treaty}

Different institutional arenas can accommodate the debates over the allocation of intergovernmental authority among federal and subnational politicians. ${ }^{21}$ If subnational politicians have institutionalized representation at the center, intra-elite bargaining tends to take place within formal state structures. By contrast, more spontaneous interactions occurring outside of formally established institutions take the shape of bargaining dominated by national and subnational executives. The treaty signing process in Russia took a form of 'executive bilateralism'22 resulting from strong pressure by subnational actors preferring $a d$ hoc bargaining. ${ }^{23}$ Therefore, this study concentrates on the factors that could give the regional executives some leverage negotiating a treaty with the president. The analysis does not include context-specific factors such as the First Chechen War that started in 1994, assuming, rather, that it had an impact on the overall willingness of the center to negotiate bilateral arrangements with the regions. ${ }^{24}$

The first condition included in the analysis is demanding sovereignty. ${ }^{25} \mathrm{In}$ June 1990, the Russian parliament passed the declaration of sovereignty and the Russian regions followed suit. Adopting these declarations, the regional governments did not aim at obtaining real independence from Russia. Instead, they sought a higher status for their regions within the new federation as well as control over economic resources within their territory. ${ }^{26}$ Bargaining that

\footnotetext{
21 Filippov, Ordeshook, and Shvetsova, (2004) and Tafel, (2011).

22 Tafel, (2011): 267-70.

23 Filippov, Ordeshook, and Shvetsova, (2004): 124.

24 This assumption is based on Tafel (2011): 263, who argues that "violent and secessionist pressures from particular regional actors are likely to produce bilateral concessions."

25 'Autonomy' would perhaps be a more precise term but 'sovereignty' is in closer alignment with Russian discourse of the 199os.

26 Daniel Treisman, "Russia's 'Ethnic Revival': The Separatist Activism of Regional Leaders in a Postcommunist Order", World Politics 49, no. 2 (1997): 212-249. Steven Solnick, "Russia's Asymmetric Federation: Are All Differences Alike?" The National Council for Eurasian and East European Research, 21 April 200o, https://www.ucis.pitt.edu/nceeer/
} 
began with assertions of sovereignty "continued with the negotiation of treaties and agreements, frequently by the very same political actors in force."27 Consequently, it is plausible that the regional executives who demanded sovereignty from the center could successfully negotiate a treaty a few years later.

The second condition is having an elected executive. Existing accounts acknowledge that the treaty negotiation process, similar to the adoption of declarations of sovereignty, was "extremely elite-dominated." 28 From initiation to signature, it involved the president and regional executives. Neither the legislative bodies nor the general public played any role in the treaty negotiation process. ${ }^{29}$ For this reason, it is important to note the different ways in which regional executives were selected. Between 1991 and 1995, some of them were appointed by President Yeltsin or by the regional legislative assemblies, while others were directly elected by the public. ${ }^{30}$ The governors having a popular mandate could have higher leverage than appointed executives both in the regions and vis-à-vis the center. ${ }^{31}$ As a result, elected executives are expected to be more successful in negotiating treaties with the center than appointed executives.

The third condition included in the analysis is voting for Yeltsin in the 1996 presidential election. During the 1996 presidential campaign, Yeltsin explicitly indicated that the treaty signing process would be discontinued if the Communist candidate, Gennady Zyuganov, won the election. ${ }^{32}$ On the other hand, Yeltsin promised that new treaties would be signed in exchange for electoral support. Therefore, the 1996 presidential election represented a 'golden opportunity' for regional executives without a treaty to obtain one. ${ }^{33}$ It is quite

200o_813-08g_Solnick.pdf (accessed 28 January 2017). Yoshiko M. Herrera, Imagined Economies: The Sources of Russian Regionalism (Cambridge: Cambridge University Press, 2005).

27 Kahn, (2000): 83.

28 Ibid., 64.

29 Stepan, (2000), Kahn, (2002), Matthew Crosston, Shadow Separatism: Implications for Democratic Consolidation (Ashgate, 2004): 11.

30 More elaboration on this difference will follow in the discussion section.

31 Steven Solnick, "The Political Economy of Russian Federalism: A Framework for Analysis", Problems of Post-Communism 43, no. 6 (1996): 13-25, Vera Tolz and Irina Busygina, "Regional Governors and the Kremlin: The Ongoing Battle for Power", Communist and Post-Communist Studies 30, no. 4 (1997): 401-426. Mikhail Filippov and Olga Shvetsova, "Asymmetric Bilateral Bargaining in the New Russian Federation: A Path-Dependence Explanation", Communist and Post-Communist Studies 32, no. 1 (1999): 73.

$32 \quad$ Filippov and Shvetsova, (1999): 73.

33 Tolz and Busygina, (1997): 404. 
likely that the regional heads supporting Yeltsin expected benefits from his re-election.

Finally, the fourth condition is the status of a donor region. Russian regions are classified as either donors to the federal budget or recipients of federal funds. Existing studies show that the regions not dependent on federal transfers were likely to obtain a treaty at the early stage of the treaty signing process. ${ }^{34}$ As the wealth of regions might also enhance "the ability of governors to promote their interests in Moscow,"35 the status of a donor region is expected to play an essential role in the treaty signing process.

Previous studies support the expectation that these four factors or conditions could lead to the outcome, a signed treaty, in their presence. This analysis, rather than untangling their average effect, aims to reveal their complex interaction and detect what conditions or combinations of conditions were necessary and sufficient for a signed treaty. As necessity means that the outcome could not be achieved without the condition and implies a very strong relationship, none of the four conditions is expected to be necessary for a signed treaty. Sufficiency requires the presence of a condition or a combination of conditions where the outcome is also present. Previous accounts demonstrate that the status of a donor region has played an important role in the treaty signing process and suggest that donor regions were more likely to obtain a treaty first. ${ }^{36}$ Furthermore, several studies concentrating on the early stage of the treaty signing process highlight that Yeltsin tended to negotiate more actively with the heads of republics who demanded sovereignty and were popularly elected. ${ }^{37} \mathrm{~A}$ combination of these three conditions - the status of a donor region, demanding sovereignty, and having an elected executive-is expected to be sufficient for a signed treaty. Based on Tolz and Busygina ${ }^{38}$ and Filippov and Shvetsova, ${ }^{39}$ voting for Yeltsin in the 1996 presidential election is expected to be sufficient at the later stage of the treaty signing process.

\footnotetext{
34 Söderlund, (2003) and Dusseault, Hansen, and Mikhailov, (2005).

35 Tolz and Busygina, (1997): 406, Cameron Ross, "Federalism and Electoral Authoritarianism under Putin", Demokratizatsiya: The Journal of Post-Soviet Democratization 13, no. 3 (2005): $347-72$.

36 Söderlund, (2003) and Dusseault, Hansen, and Mikhailov, (2005).

37 Kahn, (2000), (2002), Filippov, Ordeshook, and Shvetsova, (2004), Tafel (2011).

38 Tolz and Busygina, (1997).

39 Filippov and Shvetsova, (1999).
} 


\section{Methodology, Data and Calibration}

The study employs Qualitative Comparative Analysis (QCA), a set-theoretic method that perceives relations between social phenomena as set relations. ${ }^{40}$ QCA is associated with complex causation that involves equifinality, conjunctural causation, and asymmetry. ${ }^{41}$ Equifinality means that several conditions or combinations of conditions can produce the outcome. As a result, there might be several alternative paths leading to the same outcome. Conjunctural causation implies that a single condition leads to the outcome only in combination with other conditions and may not produce the outcome on its own. Finally, asymmetry suggests that the absence of conditions leading to the outcome may not produce the absence of the outcome. For this reason, the analyses of the occurrence and the non-occurrence of the outcome are performed separately.

QCA operates on data consisting of membership scores of cases in sets. ${ }^{42}$ Once the raw data are collected, they need to be calibrated or transformed into membership scores of cases in sets. The present study employs fuzzy-set QCA, which establishes qualitative differences in kind and in degree between the cases. ${ }^{43}$ It operates on sets where cases have full membership (1), full non-membership (o), as well as partial membership (>0.5) and partial nonmembership (<0.5). Following 'theory-guided calibration,' the cases have been assigned fuzzy-set values of $0,0.33,0.67$, and 1 in the outcome set and the conditions sets. ${ }^{44}$

\subsection{Calibration of the Outcome}

The outcome of interest is a signed treaty-further denoted as 'TREATY'. Out of 89 Russian regions, 25 were left out for a variety of reasons. First, nine autonomous okrugs that territorially belong to other regions were excluded, as their

\footnotetext{
40 Ragin, (1987).

41 Carsten Q. Schneider and Claudius Wagemann, Set-Theoretic Methods for the Social Sciences: A Guide to Qualitative Comparative Analysis (Cambridge: Cambridge University Press, 2012).

42 Ibid., 6.

43 Charles C. Ragin, Redesigning Social Inquiry: Fuzzy Sets and Beyond (Chicago: University of Chicago Press, 2008).

44 Charles C. Ragin, "Qualitative Comparative Analysis Using Fuzzy Sets (FsQCA)", in Benoît Rihoux and Charles C. Ragin eds., Configurational Comparative Methods: Qualitative Comparative Analysis (QCA) and Related Techniques (Thousand Oaks: Sage, 2009): 87-121. Ioana-Elena Oana, Carsten Q. Schneider and Eva Thomann, Qualitative Comparative Analysis (QCA) Using R: A Gentle Introduction (Cambridge: Cambridge University Press, forthcoming).
} 
inclusion would create significant ambiguity and duplication in the analysis. Second, Chechnya was excluded as negotiations with Chechnya were driven by unique motives resulting from the violent conflict there. Third, out of 43 regions with no bilateral treaty, the information on the position of the governors regarding the treaty signing process is not available for 15 regions; they were similarly excluded. ${ }^{45}$

Data on the treaty signing process was gathered via the Integrum database that contains regional and federal press reports. Texts of the treaties were collected at the official online portal of legal information. ${ }^{46}$ The regions with no treaty have either full (o) or partial (o.33) non-membership in the outcome set. The cases of failed negotiations and non-attempts to sign a treaty were assigned a score of $o$ as it is very difficult to distinguish one from the other, especially if negotiations failed at an early stage when no draft was prepared. For example, the republics of Khakassia and Ingushetia receive a score of $o$ as their heads refused to sign treaties that had been already approved by Moscow. ${ }^{47}$ Another example is Belgorod Oblast. Its governor, Evgeny Savchenko, authorized the creation of a special commission to prepare a bilateral treaty with Moscow. 48 However, negotiations failed and eventually no treaty was signed. As a result, Belgorod Oblast is similarly assigned a score of $0 .{ }^{49}$ The cases where regional officials prepared a draft of a treaty which had not been signed get a score of o.33. For instance, the governor of Kemerovo Oblast, Aman Tuleev, confirmed that the draft of a bilateral treaty had been submitted to Moscow for approval. ${ }^{50}$ Similarly, the government of Moscow Oblast finalized the draft of a bilateral treaty in $1998 .{ }^{51}$ However, neither Kemerovo nor Moscow oblasts had signed a treaty and receive a score of 0.33 .

The remaining 42 regions that managed to obtain a treaty have either partial (o.67) or full membership (1) in the outcome set. There is a substantial

45 They are the republics of Adygea, Gorno-Altay, Karachay-Cherkessia as well as Vladimir, Kamchatka, Kurgan, Penza, Pskov, Smolensk, Tambov, Tula, Tyumen, Chita oblasts, Primorsky Krai, and Chukotka Autonomous Okrug (which does not belong territorially to other regions).

46 Available at http://www.pravo.gov.ru.

$47 \quad$ Filippov and Shvetsova (1999): 74.

48 Resolution of the head of the administration of the Belgorod Oblast dated 29.04.1996 $\# 258$.

49 Later, when it was already clear that there would be no further treaties, Savchenko stated in his interview that the treaties "bear little value for the region." Quoted in Yury Antsiferov, "Tverdost Vlasti—v Sile Zakona”, Belgorodskaya Pravda, 28 November 1998.

50 Aleksandr Aleksandrov, "Aman Tuleev o Shakhtakh, Prodazhe Zemli i Ugolovnykh Delakh", Interfaks-Aif, 18 May 1998.

51 Elizaveta Domnysheva, "Novatorskii Podkhod Podmoskov'ya Vryad Li Ponravitsya Tsentry", Novye Izvestiya, 11 August 1998. 
qualitative difference between the treaties signed with the republics at the early stage of the treaty signing process and the treaties that were negotiated later. ${ }^{52}$ Similar to Tatarstan, the republics of Kabardino-Balkaria, Bashkortostan, and North Ossetia obtained extended competencies in citizenship, while the Republic of Sakha (Yakutia) secured the right to establish its own fund of precious metals and stones as well as the right to issue mining licenses and to allocate mining quotas. These five republics receive a score of 1 . On the other hand, the republics of Buryatia, Udmurtia, and Komi obtained quite modest competencies in comparison with other republics that signed a treaty earlier. Therefore, they are assigned a score of 0.67 along with the remaining 37 regions with a treaty - as these treaties did not aim to extend competencies and mainly concerned economic, legal, and cultural issues.

\subsection{Calibration of the Conditions}

Demanding sovereignty (sov). During the early 199os, the claims of regional heads represented a continuum and varied from secessionist threats to demands for greater 'sovereignty' This analysis employs a new index of regional demands of sovereignty between 1990 and 1993. It was constructed using the index of 'separatist activism' in the regions with predominantly ethnic population proposed by Treisman ${ }^{53}$ and the index of 'regional activism' in the ethnically Russian regions by Herrera. ${ }^{54}$ Additional data was collected via the Integrum database. The index includes four components: claims of unilateral change in the administrative status of the region or adoption of the declaration of sovereignty (STAT); the adoption of the regional Constitution before December 1993 (CONST); 55 the assertion that regional law takes precedence over federal law (LEG); and the assertion of economic autonomy (ECON). Except for CONST, the other indicators are weighted equally and have a maximum score of 1 . The maximum score for CONST is 2; regions that had not adopted a regional constitution or a statute by the end of 1993 but had a draft prepared receive a score of 1 (out of 2 ). The total maximum score for the index is five (see Appendix table 1 for the index). To transform the total score into

52 Mizuki Chuman, "The Rise and Fall of Power-Sharing Treaties between Center and Regions in Post-Soviet Russia." Demokratizatsiya: The Journal of Post-Soviet Democratization 19, no. 2 (2011): 133-15o. Liesbet Hooghe, Gary Marks, Arjan H. Schakel, Sandra Chapman Osterkatz, Sara Niedzwiecki and Sarah Shair-Rosenfield, Measuring Regional Authority: A Postfunctionalist Theory of Governance (Oxford: Oxford University Press, 2016).

53 Treisman, (1997): 225-28.

54 Hererra, (2005): 34-35.

55 The index by Treisman covers the period between 1990 and 1994, while the index by Herrera - the period between 1990 and 1993. Since the Constitution of the Russian Federation was adopted in December of 1993, the new index includes only the period before its adoption that is from 1990 to 1993 . 
a fuzzy-set membership score a more restrictive benchmark is set meaning the cases with the index score from o to 3 are regarded as non-members of the set of the regions demanding sovereignty. The cases with the index score of $o$ receive a fuzzy set membership score of $o$, while the cases with the index score from 1 to 3 receive a score of 0.33 . The cases with the index score of 4 and 5 are regarded as the members of the set and get a fuzzy set membership score of 0.67 and 1 , correspondingly.

Having an elected executive (ELECT). Until 1996, the heads of some regions were appointed by the president, yet the heads of others were publicly elected or appointed by regional legislative assemblies. Thilo Bodenstein has shared his dataset on Russian regional executives (personal communication, March 2018). The data were collected for the period of 1994-1996 because treaty negotiations intensified after 1994 once the first treaty with Tatarstan had been signed. As the first nation-wide gubernatorial elections took place in 1996, the distinction between appointed and elected executives is relevant only for the period before 1996. The cases when appointed governors replaced other appointees receive a score of $o$. The cases when appointed governors stayed in office during the whole period under consideration are assigned a score of 0.33 as long-standing governors were likely to have more leverage in negotiating a treaty. The cases when appointed executives were then re-elected between 1993 and 1995 receive a score of 0.67 ; and the cases when executives were elected before 1996 get the score of 1 . For example, the executives in the republics of Bashkortostan and Buryatia were elected in 1993 and 1994, respectively, and are assigned a score of 1.

Voting for Yeltsin in the 1996 presidential election (VOT). The 1996 presidential election took place in two rounds. Lavrov and Shuvalov ${ }^{56}$ provide data on electoral results in each region. The cases were calibrated in the following way. The cases receive a score of o, if the oppositional candidate (Zyuganov) had the majority of votes in a region in both rounds; and o.33, if only in the second round. The cases where Yeltsin got the majority of votes only in the second round are assigned a score of 3 , and the cases where he received the majority in both rounds get a score of 4 .

The status of a donor region (DON). Donor regions in Russia transfer a significant share of taxes collected on their territory to the federal budget and do not receive equalization grants (dotatsii na vyravnivanie) from the center. ${ }^{57}$

56 Aleksey Lavrov and Vladimir Shuvalov, Predprinimatelskii Klimat Regionov Rossii dlya Investorov i Predprinimatelei (Moskva: Nachala-Press, 1997): 278-83.

57 Natalia Zubarevich, "Dotatsiya Na Vyravnivanie Samaya Chestnaya Sredi Vsekh Transfertov Poluchaemykh Regionami”, 1o October 2018. https://otr-online.ru/programmy/segodnya -v-rossii/natalya-zubarevich-33927.html (accessed 9 November 2018). 
Crosston provides a list of donor regions in the period between 1993 and $1997 .{ }^{58}$ To calibrate the set of donor regions, the following logic applied. If between 1993 and 1997 a region had never been a donor, it gets o; if one or two times, o.33; if three or four times, o.67; and if five times, 1. However, taking into account that the republics of Tatarstan and Sakha (Yakutia) were donors before they signed their respective treaties in 1994 and 1995, they are assigned a score of 1 . The Republic of Komi similarly receives a higher score of 0.67 as it was a donor region two times in 1993 and 1994 before it signed a treaty in 1996.

\section{5}

\section{Results and Discussion}

Having calibrated the data, the next step is to perform the analysis of necessity and sufficiency. ${ }^{59}$ Necessity implies that the outcome cannot be achieved without the condition. Typically, the condition is considered necessary if it passes a consistency threshold of at least 0.9. ${ }^{60}$ As expected, none of the four conditions either in its presence or in its absence reaches the threshold of o.9. Sufficiency means that a condition or a combination of conditions is present where the outcome is also present. The analysis of sufficiency requires the creation of a truth table, which shows all logically possible combinations of conditions. The number of possible combinations is equal to $2^{\mathrm{n}}$, where $\mathrm{n}$ is the number of conditions included in the analysis. Table 1 below displays the truth table.

The first column displays the row number as it appears in the $\mathrm{R}$ output; therefore, it is not sequential. The columns two through five indicate the status of four conditions: 1 means present, o means absent. The column 'OUT' denotes whether a given row is sufficient for the outcome: 1 is sufficient, o is not. The decision about sufficiency depends on row's consistency score displayed in the column 'incl.' and PRI score showed in the column 'PRI'.61 The recom-

58 Crosston, (2004): 137 .

59 For the analyses, the R programming packages 'QCA' and 'Set Methods' were used. See Adrian Dusa, QCA with R. A Comprehensive Resource (Cham: Springer International Publishing, 2019) and Ioana-Elena Oana and Carsten Q. Schneider, "SetMethods: An Add-on Package for Advanced QCA", The R Journal 10, no 1 (2018): 507-533. Data files, the replication script as well as additional figures and tables are available at https://dataverse. harvard.edu/dataset.xhtml?persistentId=doi:10.7910/DVN/EEoDS6.

6o Charles C. Ragin, "Set Relations in Social Research: Evaluating Their Consistency and Coverage", Political Analysis 14, no. 3 (2006): 291-310.

61 PRI stands for proportional reduction in inconsistency and indicates how much it helps to know that a given condition is specifically a subset of the outcome and not a subset of the absence of the outcome. See Schneider and Wagemann, (2012): 152. 


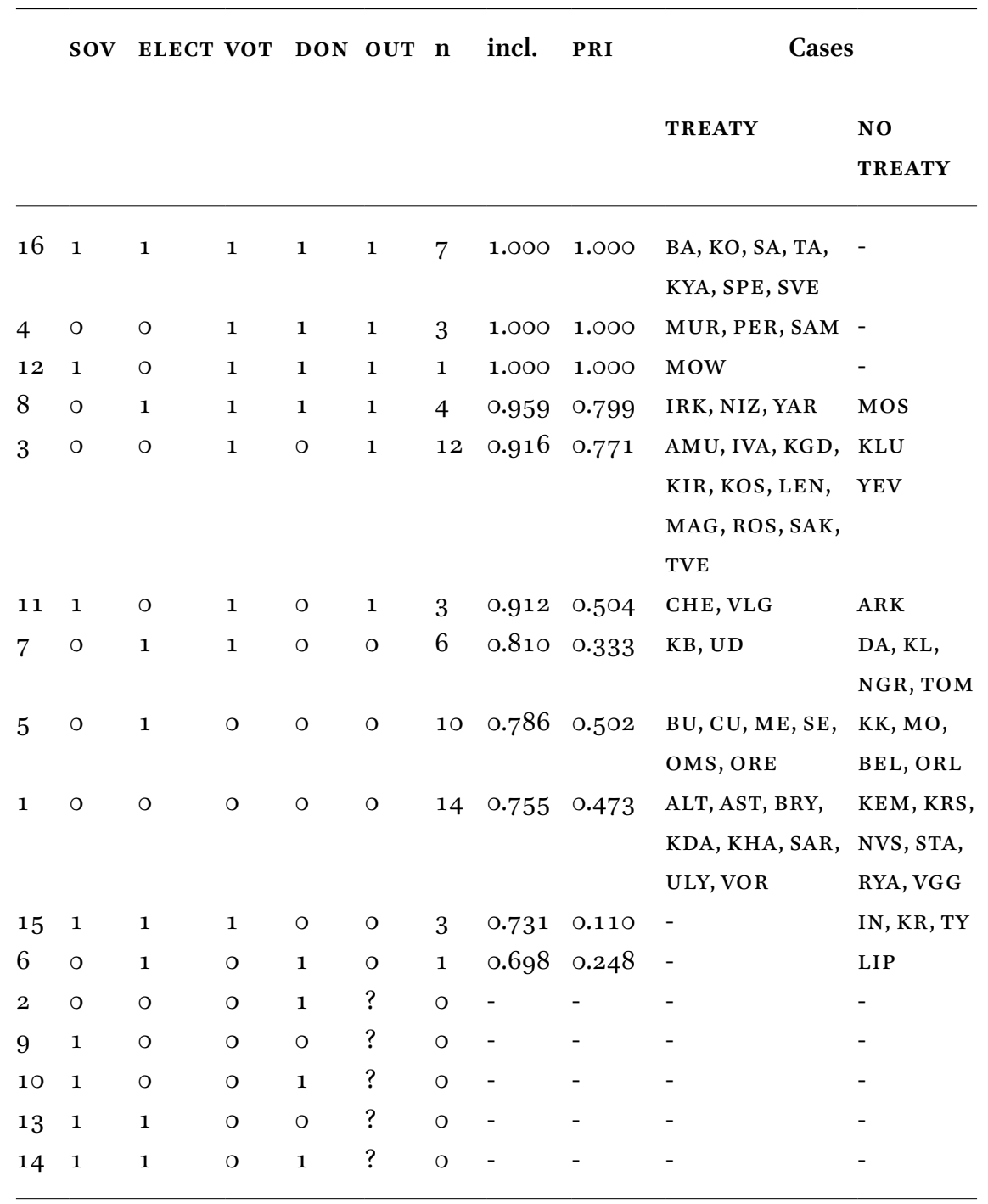

mended inclusion score for consistency is higher or equal to $0.75{ }^{62}$ Taking into account a significant gap in consistency scores between rows 11 and 7 , a consistency score equal to or higher than 0.91 and, consequently, a PRI score equal

62 Carsten Q. Schneider and Claudius Wagemann "Standards of Good Practice in Qualitative Comparative Analysis (QCA) and Fuzzy-Sets", Comparative Sociology 9, no. 3 (2010): 397-418. 
to or higher than 0.504 are set as benchmarks for sufficiency in the analysis. The column ' $n$ ' indicates the number of cases that belong to a given row; and the column 'Cases' names them. The column 'Treaty' includes the cases exhibiting the outcome and the column 'No Treaty' includes the cases displaying the absence of the outcome. Rows 2, 9, 10, 13, and 14 are so-called the logical remainder' rows - they exhibit logically possible combinations of conditions for which no empirical evidence exists. ${ }^{63}$

The analysis of sufficiency is based on minimization of sufficient truth table rows applying rules of the Boolean algebra to reduce their complexity. A standard analysis produces conservative, parsimonious, and intermediate solution formulas. ${ }^{64}$ In the present analysis, the three formulas look identical, meaning that neither simplifying assumptions nor easy counterfactuals are possible. The conservative solution formula is reported in Table 2 below.

TABLE 2 Conservative solution formula for the outcome a signed treaty

\begin{tabular}{|c|c|c|c|c|c|c|}
\hline & Cons. & PRI & $\begin{array}{l}\text { Raw } \\
\text { coverage }\end{array}$ & $\begin{array}{l}\text { Unique } \\
\text { coverage }\end{array}$ & Typical cases & $\begin{array}{l}\text { Deviant } \\
\text { cases }\end{array}$ \\
\hline VOT $^{*} \mathrm{DON}+$ & 0.889 & 0.794 & 0.388 & 0.185 & $\begin{array}{l}\text { MUR, PER, NIZ, } \\
\text { YAR, BA, IRK, KO, } \\
\text { SPE, SA, TA }\end{array}$ & MOS \\
\hline elect*vot & 0.857 & 0.699 & 0.407 & 0.205 & $\begin{array}{l}\text { CHE, IVA, KGD, } \\
\text { KIR, KOS, LEN, } \\
\text { MAG, MOW, MUR, } \\
\text { ROS, SAM, TVE, VLG }\end{array}$ & $\begin{array}{l}\text { ARK, KLU, } \\
\text { YEV }\end{array}$ \\
\hline $\begin{array}{l}\text { Overall } \\
\text { solution }\end{array}$ & o.836 & 0.724 & 0.593 & & & \\
\hline
\end{tabular}

Note: capital letters denote presence, small letters absence, ${ }^{*}$ stands for AND,+ stands for logical oR. Uniquely covered cases ${ }^{65}$ are in bold.

63 Schneider and Wagemann (2012): $15^{2}$.

64 The conservative solution is based only on empirically observed evidence, while the parsimonious solution is also based on assumptions about the logical remainders which contribute to parsimony. The intermediate solution is based only on those simplifying assumptions that at the same time represent easy counterfactuals. Therefore, the intermediate solution is often but not necessarily always less complex than the conservative solution and more complex than the parsimonious solution.

65 Uniquely covered cases display only one combination of conditions. 
The solution formula suggests that two combinations of conditions account for a signed treaty, namely, voting for Yeltsin in the 1996 presidential election ( utive (elect) and voting for Yeltsin in the 1996 presidential election (уот). ${ }^{66}$ The overall solution consistency is 0.836 . It is acceptable, yet less than one as there are several deviant cases. The solution coverage, which indicates how much of the outcome is in line with the solution, is 0.593. This coverage value is quite modest, meaning that many cases remain uncovered by these results. However, taking into account a very restrictive consistency cut-off set at o.91, this value is still quite satisfactory.

The first combination of conditions (VOT*DON) has high consistency of o.889 and decent coverage of 0.388 . Typical cases include the republics of Bashkortostan, Tatarstan, Sakha, and Komi along with Irkutsk, Nizhniy Novgorod, Perm, Yaroslavl, Murmansk oblasts, and Saint-Petersburg. Moscow Oblast is a deviant case as it displays the sufficient combination of conditions but lacks the outcome. The second combination (elect*vот) has quite decent parameters of fit-its consistency is 0.857 and coverage is 0.407 .67 Typical cases include Chelyabinsk, Ivanovo, Kaliningrad, Kirov, Kostroma, Magadan, Murmansk, Rostov, Samara, Tver, Volgograd, and Leningrad oblasts as well as Moscow. The Jewish Autonomous Oblast, along with Arkhangelsk and Kaluga oblasts, represent deviant cases.

The analysis of necessity for no signed treaty reveals no necessary conditions. The conservative solution formula is reported in Table 3 below. ${ }^{68}$

TABLE 3 Conservative solution formula for the outcome no signed treaty

\begin{tabular}{lrlllll}
\hline & Cons. PRI & $\begin{array}{l}\text { Raw } \\
\text { coverage }\end{array}$ & $\begin{array}{l}\text { Unique } \\
\text { coverage }\end{array}$ & $\begin{array}{l}\text { Typical } \\
\text { cases }\end{array}$ & $\begin{array}{l}\text { Deviant } \\
\text { cases }\end{array}$ \\
\hline SOV*ELECT $^{*}$ vot*DON & 0.900 & 0.752 & 0.101 & 0.078 & LIP & - \\
ELECT $^{*}$ VOT Ton $^{*}$ don & 0.877 & 0.707 & 0.404 & 0.382 & NGR, TOM, KB, UD \\
Overall solution & 0.877 & 0.716 & 0.482 & & IN, KL, KR
\end{tabular}

Note: capital letters denote presence, small letters indicate absence, * stands for AND, + stands for logical or. Uniquely covered cases are in bold.

66 It is important to note that although vот has appeared in both solution terms, it cannot be considered necessary because its consistency as a necessary condition is only o.651.

67 The unique coverage, which shows how much of the outcome is solely explained by the solution path, is 0.185 and 0.205 for the first and second combinations, respectively.

68 Consistency threshold is set to equal to or higher than 0.90. 
The solution formula includes two sufficient combinations of conditions, namely, not demanding sovereignty (sov), having an elected executive (ELECT) combined with not voting for Yeltsin in the 1996 presidential election (vot) and having the status of a donor region (DON) or having an elected executive (ELECT) in combination with voting for Yeltsin in the 1996 presidential election (VOT) and not having the status of a donor region (don). Solution consistency is at the acceptable level of 0.877 . Solution coverage is 0.482 , which is quite low.

The first combination of conditions (sov*ELECT ${ }^{*}$ vot $^{*}$ DON) indicates that donor regions not voting for Yeltsin in the 1996 presidential election with elected executives not demanding sovereignty did not manage to obtain a treaty. This combination has high consistency of 0.900 and displays no deviant cases. However, its coverage value is only o.1or because it explains only one case, Lipetsk Oblast. The second combination of conditions (ELECT ${ }^{*} \mathrm{VOT}^{*}$ don) suggests that the regions, which did not have the donor status, voted for Yeltsin in the 1996 presidential election and had elected executives, were unable to sign a treaty. Its consistency is 0.877 , and coverage is $0.404 .{ }^{69}$ Typical cases include Novgorod and Tomsk oblasts as well as the republics of Ingushetia, Kalmykia, and Karelia. The republics of Kabardino-Balkaria and Udmurtia represent deviant cases.

The deviant cases cast doubt on substantive sufficiency of this combination. Especially taking into account that the head of Ingushetia did not sign a draft of the treaty that had been already approved by the center. The reason, however, was not the disapproval of the treaty but "the desire to further improve the terms of the agreements." 70 Therefore, this combination provides rather inconsistent evidence for sufficiency and should not be interpreted substantially. Overall, taking into account the low coverage of the first combination and the presence of two deviant cases in the second combination, it seems that the proposed model better explains a signed treaty rather than no treaty. For this reason, the subsection below reports the results of the robustness checks performed for the analysis of a signed treaty only.

\subsection{Robustness Tests and Cluster Diagnostics}

To test the robustness of the results, Wagemann and Schneider ${ }^{71}$ suggest checking if changes in the calibration, case selection, and raw consistency levels produce any "substantively different results." Consequently, as the first

69 The unique coverage is 0.078 and 0.382 for the first and second combinations, respectively.

$70 \quad$ Filippov and Shvetsova, (1999): 74 .

71 Claudius Wgemann and Carsten Q. Schneider, "Transparency Standards in Qualitative Comparative Analysis", Qualitative \{\&\} Multi-Method Research Newsletter, no. 13 (2015): 41. 
modification the data have been calibrated following the 'direct' method. It employs a logistic function to fit the raw data in-between three qualitative anchors, that is, 1 meaning full membership, 0.5 denoting the point of indifference, and o meaning full non-membership. ${ }^{72}$ As the data calibrated via the 'direct' method normally represent numerically measured variables, ${ }^{73}$ the outcome and the conditions have been assigned numerical values based on the following logic. The cases with a treaty receive a score of 1 , and the cases with no treaty get a score of 0 , with 0.4 serving as a crossover point. This modification will also allow us to check if calibration of the outcome as a crisp (or binary) set will lead to any different results.

The condition sets ELECT and VOT have received 1 as their minimum score and 4 as their maximum, with 2.5 being a meaningful cut-off point. Two other condition sets, SOV and DON, have $o$ as their minimum and 5 as their maximum with 2.5 being selected as a crossover point. Table 4 below summarizes the calibration strategy employed in the alternative analysis.

The analysis of necessity reveals no necessary conditions. For the analysis of sufficiency, a consistency threshold is set to o.8o. It yields the same solution formula as the one produced by the original analysis. Using the newly calibrated data, the second alternative analysis has been performed with 57 cases. Seven regions (the republics of Tatarstan, Kabardino-Balkaria, Bashkortostan, North Ossetia, Sakha (Yakutia), Buryatia, and Udmurtia) those authorities negotiated a treaty earlier than the governments of other regions were excluded to test if their exclusion makes any difference in the results. For the analysis of sufficiency, a consistency threshold is set to o.8o. The results are again identical to the ones of the original analysis. The third alternative

TABLE 4 Alternative calibration strategies

\begin{tabular}{lllll}
\hline Set label & Set type & Fully out & Cross over & Fully in \\
\hline TREATY & fuzzy & O & 0.4 & 1 \\
SOV & fuzzy & 0 & 2.5 & 5 \\
ELECT & fuzzy & 1 & 2.5 & 4 \\
VOT & fuzzy & 1 & 2.5 & 4 \\
DON & fuzzy & O & 2.5 & 5 \\
\hline
\end{tabular}

72 Schneider and Wagemann, (2012): 35 .

73 Oana, Schneider, and Thomann, (forthcoming). 
analysis has been performed with the originally calibrated dataset but with lower consistency threshold set at 0.78 . This modification has allowed for the inclusion of the truth table raw 5 into the minimization procedure. The new conservative solution consists of three combinations of conditions, the first two fully resemble the results of the analyses above. The third combination is not demanding sovereignty, having an elected executive, not voting for Yeltsin in the 1996 presidential election, and not having the status of a donor region (sov* ELECT* ${ }^{*}$ vot $^{*}$ don). This combination, however, displays six typical and four deviant cases ${ }^{74}$ and, as a result, provides quite inconsistent evidence for sufficiency. Overall, none of these three modifications leads to any substantively different results than the original results meaning they are quite robust.

As Russian regions in the 1990 s varied significantly in their political regimes, ${ }^{75}$ to make sure that the sufficiency pattern revealed by this analysis holds across the regions with different regime types, cluster diagnostics has been performed. ${ }^{76}$ Using data on regional regime types by Saikkonen, ${ }^{77}$ the cases were assigned either to an authoritarian or democratic cluster. The parameters of fit for each cluster suggest that the results largely hold. ${ }^{78}$ For this reason, there is no need to include a separate condition in the analysis to account for the political regime type of the regions.

\subsection{Discussion of the Results: Back to Cases}

The analysis has yielded two combinations of conditions sufficient for a signed treaty. The first combination ( VOT $^{*} \mathrm{DON}$ ) suggests that political and economic factors have played an important role in the treaty signing process. The presence of the condition the status of a donor region (DON) is in line with the previous accounts demonstrating that donor regions were more likely to receive a treaty first. However, neither demanding sovereignty (sov) nor having an elected executive (ELECT) is a part of this combination. This result, therefore, goes beyond previously stated expectations and implies two insights.

74 Typical cases include the republics of Buryatia, Chuvashia, Mari El, North Ossetia as well as Omsk and Orenburg oblasts. Deviant cases are the republics of Khakassia and Mordovia along with Belgorod and Oryol oblasts.

75 Vladimir Gel'man, Sergey Ryzhenkov and Michael Brie, Rossiia Regionov: Transformatsiia Politicheskikh Rezhimov (Moscow: "Ves Mir", 2000).

76 Oana, Schneider, and Thomann, (forthcoming).

77 Saikkonen, (2016).

78 Pooled consistency for the combination VOT $^{*}$ DON is 0.889 , while consistency between authoritarian is 0.931 and consistency between democratic is 0.815 . Pooled consistency for the combination elect*voT is 0.857 , consistency between authoritarian is 0.857 and consistency between democratic is 0.858 . 
First, the heads of the donor regions that signed a treaty long before the 1996 presidential election had strong motives to support Yeltsin in 1996. This is because Yeltsin's re-election was a guarantee that the competencies negotiated earlier would remain in force. The main opposition candidate, Zyuganov, favored renationalization and strong central power while expressing negative attitudes regarding bilateral treaties. ${ }^{79}$ For this reason, the heads of the donor regions with a treaty publicly supported Yeltsin. For example, the president of Tatarstan, Mintimer Shaimiev, emphasized at his press-conference in February 1996 that Yeltsin granted significant economic independence to the republic by signing the 1994 bilateral treaty and explicitly stated that he would support Yeltsin in the forthcoming presidential election. ${ }^{80}$ Similarly, the head of Bashkortostan, Murtaza Rakhimov, expressed his full support to Yeltsin, pointing out that "only Boris Yeltsin can guarantee the fulfillment of bilateral treaties signed between the center and the regions." ${ }^{81}$ The president of Sakha (Yakutia), Mikhail Nikolaev, publicly supported the launching of Yeltsin's presidential campaign highlighting that the election would determine "the future of the country." ${ }^{2}$ Even Eduard Rossel, the governor of Yeltsin's native region, Sverdlovsk Oblast, emphasized that the new competencies of the treaty signed with Moscow in January 1996 would be "realized only if Russia's leadership remains stable" with Yeltsin's reelection. ${ }^{83}$

Second, the results indicate that voting for Yeltsin in the 1996 presidential election in combination with having a donor status has been sufficient for obtaining a treaty during or after the presidential campaign of 1996. Yeltsin negotiated with the governors of donor regions without a treaty during his presidential campaign, promising to sign new treaties in exchange for electoral support. The regional governments planning to sign a treaty were well aware that "Yeltsin's re-election was the best assurance that negotiated promises would indeed be honored." ${ }^{84}$ For example, a draft of the bilateral treaty with the government of Yaroslavl Oblast, where Yeltsin received the majority

79 Filippov and Shvetsova, (1999): 73.

$80 \quad$ Ildar Zakirov, "Press-Konferentsiya: Glavnoe Dostizhenie-Dogovor s Rossiei", Delovoi Mir, 7 February 1996.

81 Segodnya, "Provintsial'naya Khronika," 7 June 1996.

82 Segodnya, "Provintsial'naya Khronika", 17 April 1996.

83 Rossiiskie Vesti, "Dogovor s Uralom—Zalog Stabil'nosti Federatsii”, 19 January 1996. These cases, however, only suggest why some regional heads wanted to keep Yeltsin in power but not why they signed the treaty in the first place. I thank the anonymous reviewer for pointing out this limitation.

84 Kahn, (2002): 162. 
of votes in both rounds, was finalized only following Yeltsin's re-election ${ }^{85}$ and was eventually signed in October 1997.

The alternative combination of conditions suggests that the regions voting for Yeltsin and having appointed executives (elect*voT) managed to sign a bilateral treaty as well. This combination has not been theorized in existing literature. Supporting Yeltsin in the 1996 presidential election represented a 'golden opportunity' for regional executives without a treaty to obtain one. The new insight of the analysis is that it was not elected executives, as expected, but appointed executives who managed to negotiate a treaty following Yeltsin's re-election. For example, Yeltsin appointed the governor of Samara Oblast, Konstantin Titov, in 1991. While treaty negotiations initially started in 1995, its draft was finalized only in November 1996 following Yeltsin's re-election and the treaty was eventually signed in August $1997 .{ }^{86}$ Similarly, the mayor of Moscow, Yury Luzhkov, had the draft of a bilateral treaty prepared immediately after Yeltsin's re-election. ${ }^{87}$ While previous studies tend to focus on the early stage of the negotiation process when the treaties were signed with the heads of ethnic republics whose heads were elected, ${ }^{88}$ this analysis shows that, during the 1996 presidential campaign, appointed governors in the regions with a predominantly ethnic Russian population could obtain a treaty if they had not already had one.

Yeltsin's victory in the election did not only allow for more bilateral treaties to be signed, but also triggered a wave of popular elections. Until 1996, gubernatorial elections were postponed in all regions with the exception of the republics, whose legislation required the republican heads to be popularly elected or appointed by the regional legislative assembly. Yeltsin authorized gubernatorial elections in several regions during 1991-1995 but kept postponing their introduction nation-wide. This prohibition was supposed to prevent opposition candidates from the Communist Party from taking the governors' office. In addition, appointed governors were supposed to "facilitate the mobilization of voters" in support of Yeltsin's own re-election in 1996. ${ }^{89}$ Facing high political polarization, Yeltsin not only delayed gubernatorial elections but also co-opted the political resources of regional executives to win the 1996 presidential election.

\footnotetext{
85 Sergey Zamoraev, "Deputat i Ego Izbirately", Severnyi Krai, 9 April 1997.

86 Elena Lapshova, “Samarskaya Oblast'v Avguste 1997”, Politicheskii Monitoring, August 1997. http://igpi.ru/monitoring/1047645476/1997/o897/63.html (accessed 16 December 2019).

87 Yaroslav Skvortsov, "Status Upolnomichennykh Bankov Mozhet Izmenit'sya”, Kommersant, 10 July 1996.

88 Filippov, Ordeshook, and Shvetsova, (2004), Tafel, (2011).

89 Gel'man, Ryzhenkov, and Brie, (2000): 98.
} 
This argument implies that the regional executives were actually able to deliver expected electoral results. There is evidence confirming that the regional authorities indeed attempted to 'improve' Yeltsin's results between the two election rounds. For example, in Tatarstan, the difference between the share of votes for Yeltsin and Zyuganov was marginal in the first round, yet in the second round Yeltsin's share had significantly increased. ${ }^{90}$ The regional authorities put substantial efforts to guarantee Yeltsin's victory in the second round. Meeting with the chiefs of local administrations, they called "either to ensure Yeltsin's victory or 'to face the consequences."'91 Similar mechanisms were employed in Bashkortostan and Rostov Oblast, where Yeltsin's share in the second round was much higher than in the first round. ${ }^{92}$ In Samara Oblast, the governor fired the heads of three municipalities where Yeltsin's results were the lowest to 'improve' the performance of Yeltsin. ${ }^{93}$

These examples suggest that the treaty signing process resulted in the formation of a broad coalition between the center and subnational leaders. This is in line with previous accounts demonstrating that President Yeltsin was the first to bring the political resources of the governors to his service by promoting noncompetitive elections in the regions willing to support him. ${ }^{94}$ Putin applied this strategy nationwide. As a result, the practice of delivering votes for the center became firmly embedded in the center-region relations in Russia in the 200os.

This paper has studied the factors accounting for the signing of bilateral center-region treaties in Russia between 1994 and 1998. It has revealed that voting for Yeltsin in the 1996 presidential election and having either the status of a donor region or an appointed executive has been sufficient for a signed treaty. By providing a configurational perspective on the treaty signing process, this analysis has laid out new empirical evidence suggesting that the treaty signing process has resulted in the formation of a broad coalition between the

$90 \quad$ Akhmet Ivanov, "Respublika Tatarstan v Iyune 1996", Politicheskii Monitoring, June 1996, http://igpi.ru/monitoring/1047645476//jun1996/tatar.html (accessed 6 May 2019).

91 John Löwenhardt, "The 1996 Presidential Elections in Tatarstan", Journal of Communist Studies and Transition Politics 13, no. 1 (1997): 132-144.

92 IG PI, "Rostovskaya Oblast' v Iyune 1996", Politicheskii Monitoring, June 1996, http://igpi.ru/ monitoring/1047645476/jun1996/rost.html (accessed 9 April 2019).

93 Elena Lapshova, “Samarskaya Oblast'v Iyune-Iyule 1996", Politicheskii Monitoring, July 1996. http://igpi.ru/monitoring/1047645476/1996/o796/63.html (accessed 6 May 2019). 
center and both democratic- and authoritarian-leaning regional executives. These results support the argument by Gibson ${ }^{95}$ that "continuity or change in subnational authoritarianism is driven not by local causes alone but also by interactions between local politics and the national territorial system in which they are embedded." In contrast to the democratization of territorial regimes in Latin America where the subnational 'authoritarian enclaves' were dismantled in the course of a center-led transition, ${ }^{96}$ Russia's subnational authoritarian regimes have provided the basis for the 'authoritarian turn' at the national level in the 2000s.97

It is necessary to outline several limitations of this analysis. There is substantial difference between the regions that negotiated a treaty at the early stage of the treaty signing process and the rest, as the former received significant competencies from the center. This analysis does not explain the differences in the content of the treaties. Instead, it explains why some Russian regions managed to sign a treaty while other did not, regardless of its content. In addition, the analysis builds on the assumption that the openness of the center to treaty negotiations remained stable over time. However, it might have changed; initially, the center might have intended to sign bilateral treaties only with Chechnya and Tatarstan because of their refusal to sign the 1992 Federation Treaty. Later, the center might have been more willing to sign the treaties in exchange for electoral support. This analysis does not distinguish between the motivations of the center to sign bilateral treaties. Finally, this paper suggests that facing high political polarization, a national executive delayed not only nation-wide gubernatorial elections but also relied on political resources of governors to win the 1996 presidential election. Further research needs to investigate more in detail what role political polarization plays in a multi-level territorial setting.

\section{Acknowledgments}

I thank Julius Horvàth, Alex Astrov, Inna Melnykovska, Evelyne Hübscher, Kristin Makszin, Alex Moise, Christoph Niessen, Ingo Rohlfing, Alexey Sorbale, Andrey Starobubtsev, Élodie Fabre, Arjan Schakel, Guzel Garifullina, Justin Casey and the anonymous reviewer for helpful comments on earlier drafts of this paper.

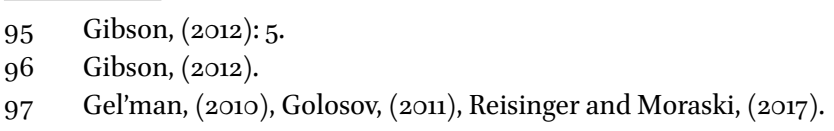




\section{Appendix}

APPENDIX TABLE 1 Index of regional demands of sovereignty, 1990-1993

\begin{tabular}{|c|c|c|c|c|c|c|c|}
\hline No & Region & Label & STAT & CONST & LEG & ECON & TOTAL \\
\hline 1 & Altai Krai & ALT & $\mathrm{o}$ & 1 & o & 1 & 2 \\
\hline 2 & Amur Oblast & AMU & 1 & o & o & 1 & 2 \\
\hline 3 & Arkhangelsk Oblast & ARK & 1 & 1 & 1 & 1 & 4 \\
\hline 4 & Astrakhan Oblast & AST & o & $\mathrm{o}$ & $\mathrm{o}$ & $\mathrm{o}$ & o \\
\hline 5 & Bashkortostan & BA & 1 & 1 & 1 & 1 & 4 \\
\hline 6 & Belgorod Oblast & BEL & o & 1 & $\mathrm{o}$ & 1 & 2 \\
\hline 7 & Briansk Oblast & BRY & o & $\mathrm{o}$ & $\mathrm{o}$ & 1 & 1 \\
\hline 8 & Buryatia & BU & 1 & 1 & $\mathrm{O}$ & 1 & 3 \\
\hline 9 & Chelyabinsk Oblast & $\mathrm{CHE}$ & 1 & 1 & 1 & 1 & 4 \\
\hline 10 & Chuvashia & $\mathrm{CU}$ & 1 & $\mathrm{o}$ & $\mathrm{o}$ & $\mathrm{o}$ & 1 \\
\hline 11 & Dagestan & $\mathrm{DA}$ & 1 & 1 & $\mathrm{o}$ & $\mathrm{o}$ & 2 \\
\hline 12 & Irkutsk Oblast & IRK & 1 & 1 & o & 1 & 3 \\
\hline 13 & Ingushetia & IN & 1 & 2 & 1 & 1 & 5 \\
\hline 14 & Ivanovo Oblast & IVA & $\mathrm{o}$ & $\mathrm{o}$ & $\mathrm{o}$ & $\mathrm{o}$ & o \\
\hline 15 & $\begin{array}{l}\text { Jewish Autonomous } \\
\text { Oblast }\end{array}$ & YEV & 1 & $\mathrm{o}$ & $\mathrm{o}$ & $\mathrm{o}$ & 1 \\
\hline 16 & Kabardino-Balkaria & $\mathrm{KB}$ & 1 & $\mathrm{o}$ & 1 & $\mathrm{o}$ & 2 \\
\hline 17 & Kaliningrad Oblast & KGD & 1 & o & o & 1 & 2 \\
\hline 18 & Kalmykia & KL & 1 & 1 & o & $\mathrm{o}$ & 2 \\
\hline 19 & Kaluga Oblast & KLU & o & o & o & o & o \\
\hline 20 & Karelia & $\mathrm{KR}$ & 1 & 2 & o & 1 & 4 \\
\hline 21 & Kemerovo & KEM & $\mathrm{o}$ & $\mathrm{o}$ & o & 1 & 1 \\
\hline 22 & Khabarovsk Krai & $\mathrm{KHA}$ & 1 & $\mathrm{o}$ & o & 1 & 2 \\
\hline 23 & Khakassia & KK & 1 & $\mathrm{o}$ & o & o & 1 \\
\hline 24 & Kirov Oblast & KIR & $\mathrm{o}$ & 1 & o & $\mathrm{o}$ & 1 \\
\hline 25 & Komi & ко & 1 & 1 & 1 & 1 & 4 \\
\hline 26 & Kostroma Oblast & Kos & o & o & $\mathrm{o}$ & o & o \\
\hline 27 & Krasnodar Krai & $\mathrm{KDA}$ & o & 1 & o & o & 1 \\
\hline 28 & Krasnoyarsk Krai & KYA & 1 & 1 & 1 & 1 & 4 \\
\hline 29 & Kursk Oblast & KRS & o & 1 & o & 1 & 2 \\
\hline 30 & Leningrad Oblast & LEN & 1 & o & o & 1 & 2 \\
\hline 31 & Lipetsk Oblast & LIP & o & o & o & 1 & 1 \\
\hline 32 & Magadan Oblast & MAG & o & o & o & 1 & 1 \\
\hline
\end{tabular}


APPENDIX TABLE 1 Index of regional demands of sovereignty, 1990-1993 (cont.)

\begin{tabular}{|c|c|c|c|c|c|c|c|}
\hline No & Region & Label & STAT & CONST & LEG & ECON & TOTAL \\
\hline 33 & Mari El & $\mathrm{ME}$ & 1 & $\mathrm{o}$ & $\mathrm{o}$ & o & 1 \\
\hline 34 & Mordovia & MO & 1 & o & $\mathrm{o}$ & $\mathrm{O}$ & 1 \\
\hline 35 & Moscow & Mow & 1 & 1 & 1 & 1 & 4 \\
\hline 36 & Moscow Oblast & Mos & $\mathrm{o}$ & 1 & $\mathrm{o}$ & o & 1 \\
\hline 37 & Murmansk Oblast & MUR & o & $\mathrm{o}$ & o & 1 & 1 \\
\hline 38 & $\begin{array}{l}\text { Nizhniy Novgorod } \\
\text { Oblast }\end{array}$ & NIZ & $\mathrm{o}$ & $\mathrm{o}$ & $\mathrm{o}$ & $\mathrm{o}$ & o \\
\hline 39 & North Ossetia & SE & 1 & 1 & $\mathrm{o}$ & $\mathrm{o}$ & 2 \\
\hline 40 & Novgorod Oblast & NGR & o & 1 & $\mathrm{o}$ & 1 & 2 \\
\hline 41 & Novosibirsk Oblast & NVS & 1 & $\mathrm{o}$ & $\mathrm{o}$ & 1 & 2 \\
\hline 42 & Omsk Oblast & OMS & $\mathrm{o}$ & $\mathrm{o}$ & $\mathrm{o}$ & 1 & 1 \\
\hline 43 & Orenburg Oblast & ORE & 1 & $\mathrm{o}$ & $\mathrm{o}$ & o & 1 \\
\hline 44 & Oryol Oblast & ORL & 1 & o & 1 & 1 & 3 \\
\hline 45 & Perm Oblast & PER & 1 & $\mathrm{o}$ & $\mathrm{o}$ & o & 1 \\
\hline 46 & Rostov Oblast & Ros & o & o & o & 1 & 1 \\
\hline 47 & Ryazan Oblast & RYA & o & o & 1 & o & 1 \\
\hline 48 & Saint-Petersburg & SPE & 1 & 1 & 1 & 1 & 4 \\
\hline 49 & Sakha (Yakutia) & SA & 1 & 2 & 1 & 1 & 5 \\
\hline $5^{\circ}$ & Sakhalin Oblast & SAK & $\mathrm{o}$ & $\mathrm{o}$ & $\mathrm{o}$ & 1 & 1 \\
\hline $5^{1}$ & Samara Oblast & SAM & $\mathrm{o}$ & $\mathrm{o}$ & $\mathrm{o}$ & $\mathrm{o}$ & o \\
\hline $5^{2}$ & Saratov Oblast & SAR & $\mathrm{o}$ & 1 & $\mathrm{o}$ & $\mathrm{o}$ & 1 \\
\hline 53 & Stavropol Krai & STA & $\mathrm{o}$ & $\mathrm{o}$ & $\mathrm{o}$ & $\mathrm{o}$ & o \\
\hline 54 & Sverdlovsk Oblast & SVE & 1 & 2 & $\mathrm{o}$ & 1 & 4 \\
\hline 55 & Tatarstan & $\mathrm{TA}$ & 1 & 2 & 1 & 1 & 5 \\
\hline $5^{6}$ & Tomsk Oblast & том & 1 & 1 & $\mathrm{o}$ & 1 & 3 \\
\hline 57 & Tuva & TY & 1 & 2 & 1 & 1 & 5 \\
\hline $5^{8}$ & Tver Oblast & TVE & o & 1 & $\mathrm{O}$ & o & 1 \\
\hline 59 & Udmurtia & UD & 1 & $\mathrm{o}$ & o & 1 & 2 \\
\hline $6 o$ & Ulyanovsk Oblast & ULY & o & $\mathrm{o}$ & $\mathrm{o}$ & o & o \\
\hline 61 & Volgograd Oblast & VGG & o & 1 & $\mathrm{o}$ & 1 & 2 \\
\hline 62 & Vologda Oblast & VLG & 1 & 1 & 1 & 1 & 4 \\
\hline 63 & Voronezh Oblast & VOR & 1 & $\mathrm{o}$ & o & 1 & 2 \\
\hline 64 & Yaroslavl Oblast & YAR & $\mathrm{o}$ & $\mathrm{o}$ & $\mathrm{o}$ & 1 & 1 \\
\hline
\end{tabular}

SOURCE: AUTHOR'S DATASET 